\title{
Perilaku Individu Dalam Menghadapi Konflik \& Pengaruhnya Terhadap Kinerja Organisasi
}

\author{
Gregorius Widiyanto \\ Manajemen, Universitas Buddhi Dharma, Banten, Indonesia
}

\begin{abstract}
ABSTRAK
Konflik merupakan masalah yang selalu muncul dalam organisasi dan tidak dapat dihindari atau dihilangkan dari kehidupan organisasi.Konflik baik secara langsung maupun tidak langsung telah menimbulkan dampak baik dampak konflik yang sifatnya fungsional akan mengakibatkan hal-hal yang positif atau bermanfaat baik bagi individu dan atau organisasi bersangkutan, sebaliknya, konflik yang tidak fungsional akan mengakibatkan hal-hal yang negatif atau merugikan bagi individu dan atau organisasi bersangkutan, maka untuk menyelaraskan dan mengatur konflik agar membantu meningkatkan kinerja organisasi secara keseluruhan dibutuhkan satu pemahaman yang utuh dan menyeluruh bagi top managemen untuk melakukan intervensi terhadap konflik yang muncul adalah mencari strategi penyelesaian masalah yang tepat, untuk itu perlu dilakukan diagonosa konflik tentang apa penyebab atau akar masalah yang memicu terjadinya konflik, siapa saja yang terlibat dalam konflik tersebut, dan apa tujuan yang sebenarnya hendak yang dicapai oleh pihak-pihak yang terlibat dalam konflik, harus dilakukan secara menyeluruh dengan memperhatikan penyebab konflik dan menerima aspirasi atau kelompok baik yang terlibat dalam konflik maupun tidak, sehingga penyelesaian konflik secara efektif dan efisien tercapai dan dapat bermanfaat untuk memperbaiki kinerja organisasi.
\end{abstract}

Kata kunci: Pola-Pola Individu, konflik 


\title{
Individual Behavior in Facing Conflict \& Its Influence on Organizational Performance
}

\begin{abstract}
Conflict is an issue that always arises in the organization and can not be avoided or eliminated from the life of the organization. Conflicts either directly or indirectly have a good impact on the impact of conflict that is functional will lead to things that are positive or beneficial for both individuals and or organizations concerned, on the other hand, non-functional conflicts will cause negative or detrimental things to the individual and or organization concerned, so to align and manage conflict to help improve the overall performance of the organization requires a complete and holistic understanding of top management to intervene the conflict that arises is to find the right problem-solving strategy, so it is necessary to diagonose the conflict about what causes or the root cause of the conflict, who is involved in the conflict, and what the real purpose hend ac achieved by the parties involved in the conflict, should be done thoroughly with regard to the causes of the conflict and accept the aspirations or groups involved in the conflict or not, so that the resolution of the conflict effectively and efficiently is achieved and can be useful for improving the performance of the organization.
\end{abstract}

Keyword: Individual Patterns, Conflict 


\section{PENDAHULUAN}

Dalam lingkungan kerja, setiap karyawan dituntut untuk dapat melaksanakan pekerjaan sesuai dengan jabatan yang dipegang dan beradaptasi dengan lingkungan serta rekan kerja yang memiliki karakter berbeda-beda. Interaksi antar individu dalam lingkungan kerja dapat menimbulkan dampak negatif yang terjadi konflik dan masalah dalam pekerjaan dan dampak positif yaitu terciptanya kondisi lingkungan kerja yang dinamis karena adanya penyesuaian terhadap tantangan dalam lingkungan internal organisasi dan eksternal organisasi karena pengaruh globalisasi, informasi, dan hubungan antar individu dalam lingkungan kerja dan dampak positif atau negatif yang ditimbulkan merupakan sumber motivasi dan kepuasan kerja yang sangat mempengaruhi kinerja organisasi, oleh karena itu sangat penting untuk menciptakan suatu kondisi lingkungan kerja yang kondusif. Ketika tidak ada pertentangan dalam organisasi dan hubungan kerja berjalan lancar akan memberikan dampak positif terhadap kinerja organisasi, tetapi ketika terdapat konflik berkepanjangan yaitu pertentangan antar individu, kelompok, bahkan organisasi yang masing-masing mengutamakan pencapaian tujuan akan membawa dampak negatif bagi kinerja organisasi. Untuk mencapai kondisi yang konduksif dalam lingkungan kerja diperlukan hubungan yang komprehensif bagi semua pihak yang berkepentingan baik itu managemen maupun kedua belah pihak secara terbuka mencoba menemukan penyelesaian yang dapat diterima oleh semua pihak, dalam hal ini manajer perlu mendorong bawahannya bekerja sama untuk mencapai tujuan bersama, melakukan pertukaran gagasan secara bebas dan menekankan usahausaha pencarian penyelesaian optimum agar tercapai penyelesaian intergratif positif kearah pencapaian tujuan organisasi secara keseluruhan meningkatkan kinerja organisasi.

\section{Definisi Konflik}

Konflik adalah suatu pertentangan yang terjadi antara apa yang diharapkan oleh seseorang terhadap dirinya, orang lain, organisasi dengan kenyataan apa yang diharapkannya. Dalam suatu organisasi yang besar, tentu akan terjadi konflik, ini tidak dapat dihindari. Konflik bias membuat suatu organisasi menjadi mantap dan berkembang, namun juga bias 
membuat organisasi/perusahaan gulung tikar. Konflik ini akan terus ada selama masing-masing pihak masih mencari kebenaran dan masing-masing, sehingga diperlukan penyelesaian kedua belah pihak yang saling menguntungkan.

Konflik dilatarbelakangi oleh perbedaan ciri-ciri yang dibawa individu dalam suatu interaksi. perbedaan-perbedaan tersebut diantaranya adalah menyangkut fisik, kepandaian, pengetahuan, adat istiadat, keyakinan, dan lain sebagainya. konflik dalam perusahaan terjadi dalam berbagai bentuk dan lain sebagainya.konflik dalam perusahaan terjadi dalam berbagai bentuk dan corak, berhadapan dengan orangorang yang mempunyai padangan yang berbeda-beda sering terjadi penggesekan, sakit hati, dan lain sebgainya, konflik yang terjadi diperusahaan sangat sering terjadi diperusahaan manapun.

Menurut Kreitner dan Kinick dalam buku Dewi Hanggraeni (2011:124) perilaku organisasi mendefinisikan bahwa : "Konflik adalah suatu proses dimana satu pihak menganggap bahwa pihak lain menentang atau menghalangi kepentingan-kepentingannya".

Menurut Greenbreg dan Baron dalam buku Dewi Hanggraeni (2011:124) prilaku

organisasi mendefinisikan bahwa: "Konflik sebagai proses dimana suatu kelompok merasa atau mempersiapkan kelompok lain akan mendapatkan atau menggunakan tindakan yang bertentangan dengan kelompoknya".

Menurut Anwar Prabu Mangkunegara (2013;155) dalam buku Manajemen Sumber Daya Manusia perusahaan mengemukakan bahwa: "Konflik adalah suatu pertentangan yang terjadi antara apa yang diharapkan oleh seseorang terhadap dirinya, orang lain organisasi dengan kenyataan apa yang diharapkan".

\section{Penyebab Timbulnya Konflik}

Konflik yang terjadi pada organisasi pada dasarnya dapat terjadi antara individu dengan individu, kelompok dengan individu maupun kelompok dengan kelompok serta antara karyawan dengan manajemen. Di mana konflik-konflik suatu organisasi memang tidak dapat dihindarkan, baik konflik yang merugikan (tidak fungsional) maupun konflik yang bermanfaat (fungsional).

Tentu saja konflik pasti ada penyebabnya. Adapun sebab-sebab timbulnya konflik antara lain: 
1. Menurut Hadyana Pujaatmaka yang dialih bahasakan oleh Robbin (2011:26) dalam buku perilaku organisasi,yaitu: “Konflik muncul karena adanya kondisi yang melatar-belakanginya.kondisi tersebut,yang disebut juga sebagai sumber terjadinya konflik,terdiri dari tiga kategori,yaitu :"

a) Komunikasi

Komunikasi yang buruk, dalam arti komunikasi yang menimbulkan kesalah pahaman antara pihakpihak terlibat, dapat menjadi sumber konflik, suatu hasil menunjukkan bahwa faktor kesalahan terdapat dalam penyampaian komunikasi.

b) Struktur

Struktur dalam konteks ini digunkan dalam artian yang mencangkup ukuran kelompok, derajat spesialisasi yang diberikan kepada anggota kelompok ,kejelasan jurisdik (wilayah kerja), kecocokan antara tujuan anggota dengan tujuan kelompok, gaya kepemimpinan, sistem imbalan dan derajat ketergantungan antara kelompok

c) Variable pribadi
Sumber konflik lainnya yang potensial adalah faktor pribadi, yang meliputi: sistem nilai yang dimiliki tiap-tiap individu, karakteristik kepribadian yang menyebabkan individu memliki keunikan dan berbeda dengan individu yang lain.

2. Menurut Drs. EC.Alex S. Nitisemito dalam bukunya Manajemen Personalia (Manajemen Sumber Daya Manusia) menyebutkan bahwa timbul organisasi disebabkan dari :

a. Intern Organisasi, terdiri dari :

1. Perbedaan Pendapat.

Perbedaan pendapat merupakan hal yang biasa dijumpai setiap saat, sehingga tidak jarang telah menimbulkan konflik. Apalagi ditunjang dengan sikap dan sifat yang berbeda antara orang satu dengan yang lain, akan menimbulkan persepsi yang berda pula. Konflik dapat menimbulkan ketegangan-ketegangan, kurang kompak dalam bekerja dan menganggu hal-hal lain, karena masing-masing pihak merasa dirinyalah yang paling benar.

2. Salah Paham 
Tidak jarang seseorang salah paham, sehingga dapat menimbulkan konflik. Hal ini sangat mungkin terjadi, karena pihak yang satu merasa dirugikan dari pihak lain. Maka pihak yang dirugikan menyanggah dan berusaha untuk membela diri, walaupun pihak lain tersebut belum tentu salah atau bertujuan tidak baik padanya.

3. Salah satu atau kedua belah pihak merasa dirugikan

Tindakan salah mungkin dianggap merugikan yang lain atau masingmasing merasa dirugikan oleh pihak-pihak tertentu. Sudah barang tentu seseorang yang dirugikan merasa kurang simpati atau justru terhambat tujuannya.

1. Perasaan yang terlalu sensitif mungkin tindakan seseorang adalah wajar, tetapi oleh pihak lain, hal ini dianggap merugikan, sehingga dapat menimbulkan konflik.

\section{b. Ekstern Organisasi,}

adapun konflik ektern organisasi yang terjadi karena dipanasi oleh pihak lain, baik langsung maupun tidak langsung yang bersifat destruktif dengan jalan mengadu domba antara pihak-pihak yang sedang konflik tersebut.

3. Menurut Heidjrachman Ranupandoyo dan Suad Husnan, dalam buku Manajemen Personalia, timbulnya konflik ada beberapa hal yaitu:

a. Berbagai sumber daya yang langka Pengalokasian terhadap sumber daya yang langka dapat menimbulkan konflik, karena dimungkinkan pengalokasian tersebut dianggap tidak adil atau kurang seimbang.

b. Perbedaan dalam tujuan

Setiap organisasi tentu saja mempunyai tujuan yang telah ditetapkan sebelumnya. Di mana tujuan organisasi yang satu dengan yang lain berbeda-beda. Dalam suatu organisasi terdiri dari bagian-bagian yang berbeda. Misalnya bagian produksi, bagian pemasaran, bagian keuangan dan sebagainya. Seringkali tujuan-tujuan tersebut saling berbenturan dengan kepentingan tiap bagian, sehingga dapat menimbulkan konflik.

c. Saling ketergantungan dalam menjalankan pekerjaan

Setiap organisasi terdiri unit/bagian yang saling menunjang antara satu dengan yang lain dan berhubungan. 
Sebagai akibat dari interaksi individu dan atau organisasi bersngkutan unit/bagian tersebut dapat (EC.Alex S.Nitisemito, 1984;214)

memungkinkan timbulnya kerugian 1. Akibat Positif/Bermanfaat unit/bagian tertentu.

a. Menimbulkan kemampuan

d. Perbedaan dalam menilai atau mengoreksi diri sendiri

persepsi

Perbedaan sikap, nilai atau persepsi seseorang sangat memungkinkan menimbulkan konflik. Bahkan konflik akibat perbedaan ini mendasar sehingga ketegangan masing-masing pihak dapat mengakibatkan kemacetan organisasi.

e. Sebab-sebab lainnya

Penyebab timbul konflik lainnya adalah ketidakjelasan organisasi, gaya kepemimpinan, gaya seseorang dalam pekerjaan, dan lain-lain.

\section{Akibat Adanya Konflik:}

Konflik baik secara langsung maupun tidak langsung telah menimbulkan dampak baik dampak konflik yang sifatnya fungsional akan mengakibatkan hal-hal yang positif atau bermanfaat baik bagi individu dan atau organisasi bersangkutan, sebaliknya, konflik yang tidak fungsional akan mengakibatkan halhal yang negatif atau merugiakan bagi
Setiap individu atau kelompok dengan adanya konflik dapat merenungi kembali apa yang dibicarakan dan atau diperbuat. Dengan merenung dan mengingatingat kembali akan dapat mengoreksi kembali, mana pembicaraan dan atau perbuatan yang telah dilakukan yang menyinggung perasaan lawan bicara, sehingga menimbulkan konflik. Dengan tindakan tersebut dapat segera mengetahui sumber konflik dari mana, apakah dari pribadi atau dari orang lain atau pihak-pihak tertentu. Karena setiap apa yang dibicarakan atau diperbuat belum tentu benar menurut orang lain, sehingga harus ada penyesuaian dengan lawan bicara yang dihadapinya.

b. Meningkatkan Prestasi

Banyak orang yang memanfaatkan konflik untu lebih banyak belajar sebagai pengalaman untuk meningkatkan skill dalam prestasinya dalam bekerja, 
hakekatnya konflik justru membuat seseorang termotivasi untuk mencari jalan penyelesaian permasalahan yang ada. Dengan begitu akan menghasilkan hal-hal yang baru dan diterima oleh masing-masing pihak yang berkonflik, biasanya orang lebih tertantang untuk menunjukkan kemampaun untuk berprestasi sesuai dengan bakat, ketrampilan atau skill yang dimilikinya.

c. Pendekatannya yang lebih baik, Dengan adanya konflik menyebabkan seseorang akan selalu berhati-hati di dalam berhubungan dengan orang lain dari segala perkataan, perbuatan,, sebab sesuatu yang benar bagi dirinya belum tentu benar menurut orang lain.Hal ini harus disadari sepenuhnya, di mana sikap, sifat, perkataan, perbuatan adalah dirinya belum tentu benar menurut orang lain, manusia di ciptakan berbeda dan unik satu dengan yang lain.

2. Akibat Negatif/ Merugi yang diakibatkan oleh konflik

a. Menghambat kerja sama, jika konflik sudah mencapai tingkat yang parah akan menimbulkan keteganganketegangan, sehingga sulit kedua belah pihak untuk terjalin kerja sama, tentu saja rasa kurang menyenangkan sudah barang tentu menyudutkan mereka bekerja dalam kekakuan.

b. Subyektif dan emosional, emosional dalam konflik sudah barang tentu umum dan yang merugikan adalah sifat emosional yang tak terkendalikan, akan membawa jalan pemikiran yang kurang sehat, sehingga dengan begitu pandangan antara yang berkonflik selalu subyektif, yaitu apa yang dilakukan serba salah menurut pandangan mereka dan sebaliknya.

c. Apriori, sifat subyektifitas dan emosional pada umumnya selalu diikuti sikap apriori atau acuh tak acuh terhadap sekitarnya, karena sikap perbuatan pihak lain yang berkonflik akan selalu salah dan pihaknyalah yang selalu benar. Hal ini sangat mempengaruhi jalannya suatu organisasi dalam mencapai tujuan yang akan dicapai.

d. Saling menjatuhkan, pihak-pihak yang berkonflik tidak jarang juga melakukan saling menjatuhkan lawan dengan berbagai jalan yang ditempuh. 
e. Frustasi/ rasa putus asa dapat terjadi bagi mereka yang mengalami lemah mental, ini tentu saja akan merugikan pihak atau individu tersebut dengan akibatnya.

\section{Pola-pola Perilaku Individu Dalam}

\section{Menghadapi Konflik}

Pada setiap orang/individu mempunyai pola-pola tertentu untuk menghadapi situasi yang bertentangan dengan pendapatnya atau jalan pemikirannya. Terutama situasi yang tidak menyenangkan. Dalam menghadapi situasi yang tidak menyenagkan. Dalam menghadapi situasi yang demikian kemampuan seseorang akan dipengaruhi oleh kematangan emosi (Emotional Maturity), dan tingkat pendidikan serta dikuatkan oleh pengalaman-pengalaman selama ia menghadapi konflik.

Cara-cara seseorang dalam menghadapi konflik akan membawa pengaruh pada bagaimana suatu konflik diatur, sehingga dicapai keselerasan. Disamping itu sebagai upaya preventif setiap munculnya konflik yang lain atau yang lebih berlanjut sifatnya.

Menurut Thomas-Kilmann melakukan pendekatan dengan dasar 2 dimensi yaitu:
1. Asertifitas adalah suatu pola individu menghadapi konflik dengan mengupayakan kepuasan dirinya.

2. Kooperatifitas adalah suatu pola individu menghadapi dengan mengupayakan kepuasan bagi pihak lain.

Dari hasil kedua dimensi tersebut kemuadian dikembangkan lagi menjadi lima tipe atau pola perilaku dalam menghadapi konflik, yaitu:

1.

Competing

(Asertifitas-

Kooperatifitas)/bersaing

Pada dasarnya orientasi bersaing disini adalah individu unjuk kekuatan. Dengan menggunakan segala bentuk kekuatan yang dimiliki misalnya, keuangan, kedudukan/jabatan, kekuasaan dan sebagainya untuk menekan pihak lain yang dianggap sebagai saingan, dan sumber konflik. Dengan demikian individu mencoba memaksakan pemenuhan kepuasan dirinya pada orang lain. Cara Competing/bersaing digunakan dengan memaksa jika :

- Memerlukan tindakan cepat

- Permasalahan sangat penting

- Diperlukan untuk kepentingan perusahaan dan kita merasa benar 
- Melawan orang yang ingin memanfaatkan keadaan "damai"

2. Accommodating/Penyesuaian/Non asertifitas-kooperatifitas.

Didalam bersikap untuk menghadapi konflik individu mengalah pada kepentingan pihak lain guna memberikan kesempatan. Sementara waktu ia akan patuh apa yang dikenakan atas dirinya. Konsekuensinya harus menjalankan apa yang diputuskan pihak tersebut, sekalipun hal itu tidak sejalan dengan pendapatnya

- Kita dipihak yang salah

- Masalah lebih penting daripada "Ego"

- "Deposito" untuk kemudian hari

- Mengurangi kerugian kalau kita ternyata kalah besar

- Agar bawahan belajar dari kesalahan

3) Collaborating/Kerja sama (AsertifitasKooperatifitas)

Sikap individu yang diambil adalah kerjasama dengan pihak lawan untuk mendapatkan pemecahan permaslahan yang terbaik dan saling menguntungkan serta memberikan kepuasan yang sama. Individu harus memahami cara pandang dan pemikiran pihak lawan dan mencari sumber-sumber mana yang dimiliki dan tidak dimiliki kedua belah pihak. Cara Collaborating/Kerja sama (Asertifitas-Kooperatifitas) digunakan jika:

- Kedua kepentingan terlalu mahal untuk dikompromikan

- Untuk mendapatkan komitmen

- Menggabungkan pemahaman dari orang-orang yang berbeda perpektif

- Mengatasi perasaan yang pernah menganggu hubungan.

4). Avoiding/Menghindar (Non Assertifitas-Kooperatifitas) Sikap individu berusaha menghindar dan apriori terhadap konflik yang terjadi, tetapi individu bukan berarti terlepas dari tugas dan tanggung jawab yang dibebankan. Namun ia menganggap seakan konflik itu tidak pernah ada. Hal ini bertujuan jangan sampai konflik menjadi besar dan meluas.

Cara Avoiding/menghindar digunakan jika :

- Masalah sepele

- Tak ada kemungkinan memenuhi kepentingan kita

- Kehancuran lebih besar dari manfaatnya

- Cooling down 
- Kalau orang lain mampu menyelesaikan

5)

\section{(Asertifitas-kooperatifitas)}

Setiap individu mencari satu pemecahan permasalahan yang dapat diterima semua pihak. Tipe atau pola ini tidak mencoba memaksakan kehendaknya tetapi juga tidak mau mengalah begitu saja. Dalam menerima konflik, individu tidak akan segera menghindar/lari.

Cara Kompromi/persetujuan digunakan jika :

- Kekuatan dua pihak sama besar untuk sama besar untuk saling meniadakan

- Untuk mencapai penyelesaian sementara

- Untuk sampai pada solusi yang pantas mengingat tekanan waktu

Setiap orang/individu sebenarnya sudah mempunyai potensi untuk menggunakan kelima perilaku dalam menghadapi konflik. Di mana individu yang mempunyai ketrampilan dalam menggunakan pola ini, biasanya dapat luwes menganti satu pola dengan pola yang lain, sesuai dengan jenis konflik dan siapa yang dihadapi.

\section{Pengaruh Konflik terhadap Kinerja Organisasi}

Konflik merupakan selalu muncul dalam organisasi dan tidak dapat dihindari, meskipun tidak dapat diprediksi apakah konflik tersebut akan berdampak negatif (bersifat disfungsional atau positif (bersifat fungsional) terhadap kelangsungan hidup organisasi. Konflik fungsional adalah tipe konflik yang mendukung pencapaian tujuan atau sasaran-sasaran organisasi serta meningkatkan kinerja, sedangkan konflik disfungsional adalah tipe konflik yang justru menghambat kinerja organisasi. Konflik fungsional juka dikelola secara efektif akan membantu meningkatkan kinerja organisasi karena memungkinkan organisasi dalam memperbaiki strategi, system reward maupun meningkatkan produktivitas kerja anggota organisasi yang bermanfaat bagi perkembangan dan inovasi yang secara otomatis akan mempengaruhi kinerja secara keseluruhan, oleh karena itu konflik yang terjadi harus diupayakan untuk menjadi konflik yang fungsional dan dalam situasi inilah sangat diperlukan peran aktif top management untuk mengatasi setiap masalah yang ada. 
Tindakan pertama dalam melakukan tersebut berada pada level tinggi atau intervensi terhadap konflik yang muncul rendah, tindakan apa yang seharusnya adalah mencari strategi penyelesaian dilakukan sesuai dengan kondisi konflik masalah yang tepat, untuk itu perlu sehingga manajer dapat memutuskan dilakukan diagonosa konflik tentang apa strategi yang tepat untuk menciptakan penyebab atau akar masalah yang memicu konflik tersebut menjadi konflik yang terjadinya konflik, siapa saja yang terlibat bersifat fungsional dan berdampak positif dalam konflik tersebut, dan apa tujuan terhadap kinerja organisasi. yang sebenarnya hendak yang dicapai oleh pihak-pihak yang terlibat dalam konflik (Brown, 1995) dalam bukunya Anatan \& Elitan (2009:64), jika jawaban sudah diketahui, perlu diagnosis apakah konflik

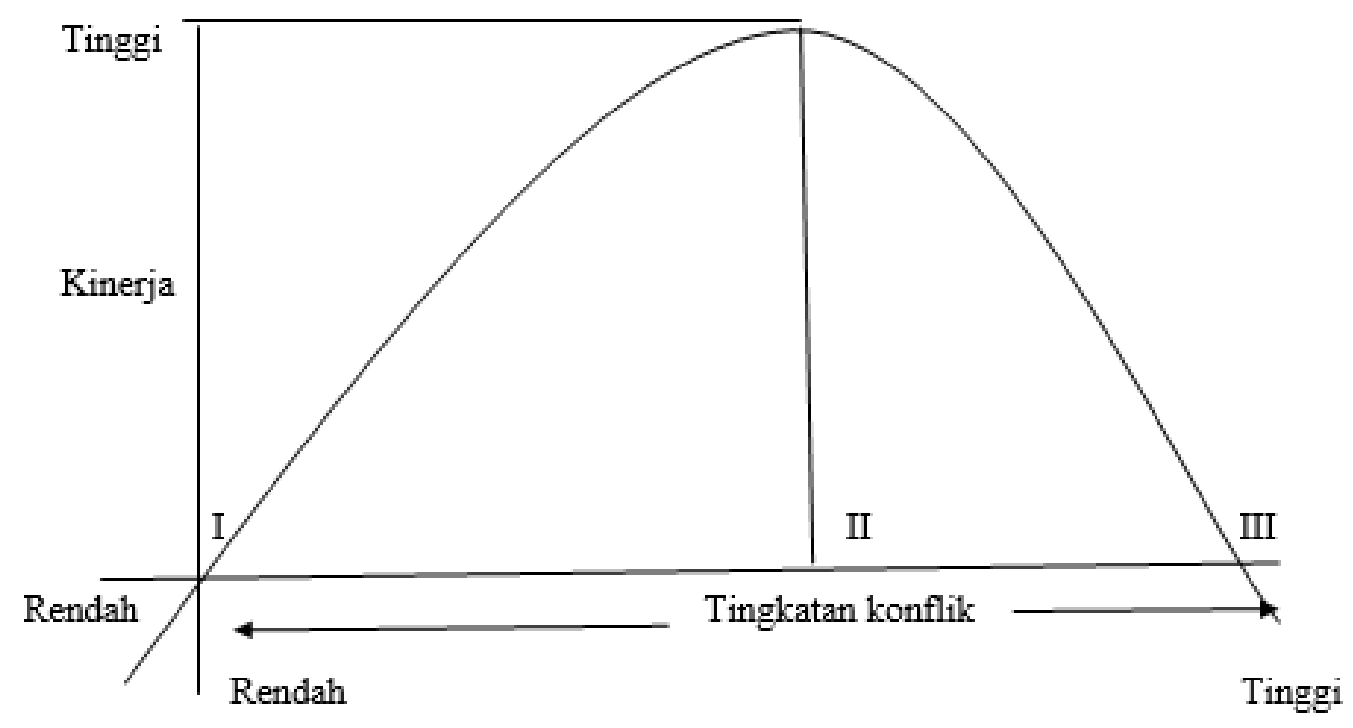

Konflik \& Kinerja Unit 


\begin{tabular}{|c|c|c|c|c|}
\hline & & & & \begin{tabular}{l|l} 
- & Kacau balau \\
- Tidak dapat \\
bekerja sama
\end{tabular} \\
\hline Situasi & $\begin{array}{c}\text { Tingkatan } \\
\text { Konflik } \\
\text { Antar } \\
\text { Kelompok }\end{array}$ & Sifat Konflik & $\begin{array}{c}\text { Karakteristik } \\
\text { Organisasi }\end{array}$ & - Pada gambar dan table diatas \\
\hline I & $\begin{array}{l}\text { Rendah } \\
\text { atau tidak } \\
\text { ada } \\
\text { konflik }\end{array}$ & Disfungsional & $\begin{array}{l}\text { - } \text { Adaptasi } \\
\text { yang lambat } \\
\text { terhadap } \\
\text { perubahaan } \\
\text { lingkungan } \\
\text { - Sedikit } \\
\text { perubahaan } \\
\text { - Apatis } \\
\text { - Stagnasi }\end{array}$ & $\begin{array}{l}\text { Rendah } \\
\text { menunjukkan tingkat konflik yang } \\
\text { rendah dan tingkat konflik yang tinggi } \\
\text { kinerja organisasi mencapai level kinerja } \\
\text { yang sangat rendah pada ( I dan II), } \\
\text { sedangkan kinerja organisasi mencapai } \\
\text { tingkat titik optimal (II), Pada tingkat } \\
\text { konflik yang rendah atau tidak ada }\end{array}$ \\
\hline II & Optimal & Fungsional & $\begin{array}{l}\text { - Gerakan } \\
\text { positif kea } \\
\text { rah } \\
\text { pencapaian } \\
\text { tujuan } \\
\text { - Kreativitas } \\
\text { dan adaptasi } \\
\text { yang cepat } \\
\text { terhadap } \\
\text { perubahaan } \\
\text { lingkungan } \\
\text { - Bersemangat } \\
\text { terhadap } \\
\text { inovasi } \\
\text { perubahaan } \\
\text { yang } \\
\text { mengarah } \\
\text { pada diri } \\
\text { sendiri }\end{array}$ & 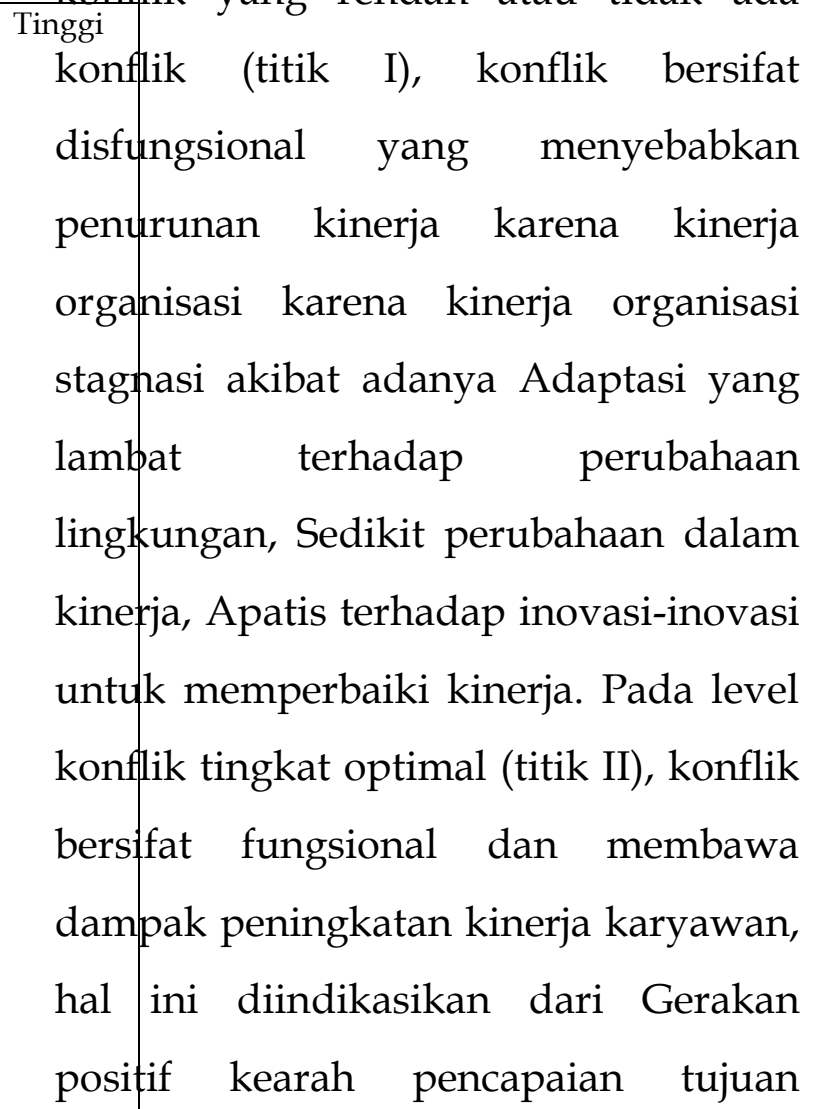 \\
\hline III & Tinggi & Disfungsional & $\begin{array}{l}\text { - Gangguan } \\
\text { berat } \\
\text { Menganggu } \\
\text { aktivitas } \\
\text { - Sulit } \\
\text { berkoordinasi }\end{array}$ & $\begin{array}{l}\text { Rendah } \\
\text { organisasi, kreativitas dan adaptasi yang } \\
\text { cepat terhadap perubahaan lingkungan, } \\
\text { bersemangat terhadap inovasi } \\
\text { perubahaan yang mengarah pada diri }\end{array}$ \\
\hline
\end{tabular}


tinggi, konflik bersifat disfungsional dan membawa dampak penurunan kinerja organisasi karena tingkat tingkat konflik yang tinggi akan banyak waktu dan sumber daya yang dipakai untuk mengatasi konflik-konflik yang terjadi, kondisi ini dikarakterisasikan adanya Gangguan berat Menganggu aktivitas organisasi, sulit berkoordinasi antar departemen-departemen/ lini dalam organisasi, kacau balau dalam organisasi, dan tidak dapat bekerja sama antar satu sama dengan yang lain.

\section{Cara Mengelola \& Penyelesaian Konflik Dalam Organisasi}

Konflik tidak dapat dihindari dapat memberikan pengaruh positif bagi kinerja organisasi tergantung kita mengelola konflik yang terjadi. Pengelolaan konflik harus didasarkan pada sebab/tingkat konflik, hal ini dikarenakan sebab-sebab konflik berlainan antara satu konflik dengan konflik yang lain sehingga dibutuhkan metode yang dapat digunakan mengelola konflik. Dalam mengelola konflik \& Penyelesaian konflik dalam organisasi ada tiga cara metode yang digunakan yaitu (Veithzal Rivai, 2004:514): a).Metode Stimulasi Konflik, metode ini digunakan untuk menimbulkan rangsangan anggota, karena anggota pasif yang disebabkan oleh situasi di mana konflik rendah, sehingga metode ini sengaja diugunakan manajer untuk merangsang agar konflik tersebut produktif. Metode stimulasi konflik ini meliput :

1) Pemasukan atau penempatan orang ke dalam kelompok yang latar belakang, nilai, sikap dan gaya manajerial berbeda dari anggotaanggota yang ada dalam kelompok

2) Penyusunan kembali organisasi dengan mengatur ulang kelompokkelompok kerja, mengubah tatanan dan peraturan, meningkatkan kesalingbergantungan antara satu kelompok dengan kelompok yang lain, membuat perubahaan yang serupa untuk mengacaukan status quo dalam organisasi

3) Penawaran bonus, pembayaran insentif dan penghargaan untuk mendorong persaingan yang sehat

4) Pemilihan manajer-manajer yang tepat sesuai dengan kemampuan dan keahlian yang dimiliki

5) Menunjuk seorang pengritik untuk dengan sengaja beragumen menentang pendirian mayoritas yang dipegang oleh kelompok tertentu. 
b).Metode Pengurangan Konflik, metode ini digunakan untuk mengelola tingkat konflik melalui 'Pendinginan suasana' tetapi tidak menangani masalahmasalah yang semua menimbulkan konflik, metode pengurangan konflik ini meliputi

1) Menganti tujuan yang menimbulkan persaingan dengan tujuan yang lebih bisa diterima oleh kedua kelompok yang sedang konflik

2) Mempersatukan kedua kelompok yang bertentangan unttuk menghadapi konflik yang sama dengan ' ancaman' atau 'musuh' yang sama sebagai sumber konflik

\section{c).Metode Penyelesaian Konflik, dalam} metode ini yang sering digunakan untuk menyelesaikan konflik antara lain :

1) Dominasi dan penekanan pada pihak-pihak yang terjadi konflik di mana yang menang akan dapat menguasau jalannya organisasi, sebaliknya yang kalah memberikan jalan pada pihak yang menang, dominasi atau penekanan dapat dilakukan dengan beberapa cara yaitu:
- Kekerasan (forcing) di mana kekerasan dengan kekuasaan dan wewenang yang dimiliki pimpinan berusaha menyelesaikan konflik yang terjadi dengan menggunakan penekanan otoktarik yang dimilikinya.

- Negosiasi merupakan pertemuan antara pihak yang mempunyai kepentingan yang berbeda atau pihak yang sedang mengalami konflik dan secara bersama-sama berusaha mencapai persetujuan bersama.

- Penghindaran (avoidance) di mana manajer menghindar untuk mengambil posisi yang tegas, ketika konflik sudah menanas, menyegarkan situasi dan mengembalikan sudut pandang yang obyektif, memberikan waktu untuk mencari informasi guna menyelesaikan konflik dalam jangka panjang, dan masalahmasalah yang penting yang harus diutamakan.

- Aturan mayoritas (majority rule), mencoba untuk menyelesaikan konflik antar kelompok dengan melakukan pemungutan suara (voting) melalui prosedur yang 
adil yang dapat diterima oleh

kelompok yang berkonflik.

2) Kompromi, manajer mencoba menyelesaikan konflik melalui jalan tengah yang dapat diterima oleh kedua belah pihak yang bertikai, bentuk kompromi ini meliputi

- Pemisahan (separation), dimana pihak-pihak yang sedang bertikai dipisahkan sampai mereka mencapai presetujuan bersama dalam menyelesaikan permasalahan

- Perwasitan (arbitrasi), melibatkan pihak ketiga (mediator, arbitrator, perujuk, dan konsultan) sebagai penengah yang mengemukakan pendapatnya secara jujur tentang masalah yang dihadapi dan menawarkan penyelesaian kepada pihak yang terlibat berkonflik.; Pihak ketiga terdiri dari: (Robbin,1996:161)

- Mediator, memggunakan sarana mediasi untuk mempermudah pemecahan masalah dengan menggunakan penalaran, persuasi, dan saransaran alternative beserta solusi yang dapat diterima pihakpihak yang terlibat berkonflik.
- Arbitrator, menggunakan otoritas yang dimilikinya untuk memaksakan kehendaknya suatu persetujuan kepada pihak berkonflik

- Perujuk, pihak ketiga yang dipercaya yang memberikan komunikasi informal antara perunding dengan lawan yang berkonflik.

- Konsultan, orang mempunyai skill, keahlian yang terampil dan tidak berat sssebelah dalam mengambil keputusan yang berupaya memudahkan pemecahan masalah lewat komunikasi, analisis, pengetahuan yang mendukung mengenai manajemen konflik.

- Kembali keperaturan-peraturan yang berlaku, di mana kemacetan/kebuntuan menyelesaikan permasalahan dikembalikan pada ketentuanketentuan tertulis yang berlaku dan menyetujui bahwa peraturanperaturan yang memutuskan penyelesaian konflik;

- Penyuapan (bribing), di mana salah satu pihak menerima kompensasi 
dalam pertukaran untuk tercapainya penyelesaian konflik

3) Pemecahan masalah integratif (secara menyeluruh), konflik antar kelompok diubah menjadi situasi pemecahan masalah bersama melalui teknikteknik pemecahan masalah, disamping penekanan konflik atau pencarian kompromi, kedua belah pihak secara terbuka mencoba menemukan penyelesaian yang dapat diterima oleh semua pihak, dalam hal ini manajer perlu mendorong bawahannya bekerja sama untuk mencapai tujuan bersama, melakukan pertukaran gagasan secara bebas dan menekankan usaha-usaha pencarian penyelesaian optimum agar tercapai penyelesaian intergratif. Metode pemecahan masalah integratif, ini terdiri dari :

- Konsensus, kedua belah pihak bertemu bersama-sama untuk mencari penyelesaian terbaik masalah mereka dan bukan mencari kemenangan satu pihak;

- Konfrontasi, kedua belah pihak menyatakan pendapatnya secara langsung satu dengan yang lain, dan dengan kepemimpinan yang terampil serta kesediaan untuk menerima penyelesaian, suatu penyelesaian konflik yang rasional sering dapat ditemukan;

- Kolaborasi, untuk mmuaskan kepentingan semua pihak yang terlibat dalam konflik; pihak yang terlibat di dorong untuk menyelesaikan masalah yang mereka hadapi dengan jalan mencari dan menemukan persamaan-persamaan kepentingan dan bukan perbedaan-perbedaannya.

- Mengelak, sikap seseorang atau suatu kelompok yang mengakui bahwa memang terdapat konflik dalam hubungan dan interaksinya dengan orang lain/kelompok lain, akan tetapi yang bersangkutan ingin menarik diri/ menekan konflik sehingga tidak semakin meruncing

\section{PENUTUP}

Konflik antar kelompok sebagai salah satu jenis konflik organisasi, merupakan masalah yang selalu muncul dalam organisasi dan tidak dapat dihindari atau dihilangkan dari kehidupan organisasi. Konflik ini dapat memberikan dampak 
positif atau negatif terhadap kinerja perusahaan tergantung pada sifat dan tingkat level dan bagaimana konflik tersebut dikelola secara efektif untuk menjadi konflik yang optimal sehingga tercapai peningkatan kinerja. Konflik yang terjadi dalam organisasi tidak harus dihindari atau dihilangkan melainkan harus diciptakan suatu kondisi konflik yang bersifat fungsional pada level optimal sehingga memberikan pengaruh positif terhadap kinerja perusahaan. Untuk penanganan konflik harus dilakukan secara menyeluruh dengan memperhatikan penyebab konflik tentang apa penyebab atau akar masalah yang memicu terjadinya konflik, siapa saja yang terlibat dalam konflik tersebut, dan apa tujuan yang sebenarnya hendak yang dicapai oleh pihak-pihak yang terlibat dalam konflik dan menerima aspirasi atau kelompok baik yang terlibat dalam konflik maupun tidak, sehingga penyelesaian konflik secara efektif dan efisien tercapai dan dapat bermanfaat untuk memperbaiki kinerja organisasi.

\section{DAFTAR PUSTAKA}

- $\quad$ Alex S. Nitisemito, 1984, Manajemen Personalia (Manajemen Sumber
Daya Manusia, Jakarta, Ghalia Indonesia

Brown, L.David, 1995. Managing Conflict Among Groups. In: The Organizational Behavior Reader, 6 th Edition, Kolb, David A,. Joyce S.Oslance, Irwin M Rubin Prentice Hall: International Edition, New Jersey

Danang Sunyoto \& Burhanudin, 2011, Perilaku Organisasional, Yogyakarta, CAPS

Heidjrachman Ranupandoyo; Suad Husnan; Manajemen Personalia, Yogyakarta, BPFE, 1980

Robbins, Stephen P., 1986 Perilaku Organisasi: Konsep-KontroversiAplikasi, Edisi Alih Bahasa: Hadiyana Pujaatmaka, Jilid 2, PT. Prenhallindo, Jakarta

Lina Anatan \& Lena Ellitan, 2009, Manajemen Sumber Daya Manusia dalam Bisnis Modern, Cetakan kedua Alfabeta, Bandung

Wahjosumidjo, 1997, Kepemimpinan dan Motivasi, Cetakan Ketiga, Jakarta: Ghalia Indonesia

- Veithzal Rivai, 2004, Manajemen Sumber Daya Manusia untuk Perusahaan Dari Teori ke Praktik, 
Murai Kencana, PT Rajagrafindo

Persada, Jakarta. 